\title{
Teaching Strategies for Enhancing Student's Learning
}

\author{
Zeinab Abulhul (Corresponding author) \\ Department of Social Work Education, School of Health and Human Services, Widener University, Chester, PA, USA. \\ Department of Social Work, University of Tripoli, Tripoli, Libya \\ Email: zaino.abulhul@gmail.com
}

Received: 21/01/2021

Accepted: 03/04/2021

Published: 01/05/2021

Volume: 2 Issue: 3

How to cite this paper: Abulhul, Z. (2021). Teaching Strategies for Enhancing Student's Learning. Journal of Practical Studies in Education, 2(3), 1-4

DOI: https://doi.org/10.46809/jpse.v2i3.22

Copyright $\odot 2020$ by author(s) and Global Talent Academy Ltd. This work is licensed under

the Creative Commons Attribution International License (CC BY 4.0).

http://creativecommons.org/licenses/by/4.0/

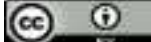

\begin{abstract}
There are various teaching methods and learning styles. These methods mostly focus on students' learning capacities for better understanding and engagement. Educational principles and pedagogy focus on the type of students' learning, the type of teaching tool, and the classroom environment. These three aspects can help students and instructors facilitate the learning process and make it easily absorbable. This paper aims to shed light on various teaching strategies and class activities that instructors could use in their teaching methods to enhance student's learning. The author shows five strategies that are effective for teaching college students. These strategies can help students meet their educational needs and stimulate their brains to expand their knowledge and learning. These methods are as follows: presenting short lectures to refresh students' attention to the class lesson and help their brains come up with ideas about the topic based on their daily experience, brainstorming that is a class group activity helping students work together and learn how to value each other opinions, group reports that encourage students to be familiar with strategies of writing a report as a conclusion for the group meeting, technology-based activities that develops students' educational skills in broadening their self-learning, and PowerPoint presentation that helps students review what they have learned in the class.
\end{abstract}

Keywords: Teaching Techniques, Critical Thinking, Class Activities, Learning Procedure

\section{Introduction}

Teaching methods that consider the interaction between students and their instructors have a positive effect on students' learning. The most effective strategy that Instructors use to benefit student's learning in the classroom is to encourage them to link their experience in learning in the past to the new knowledge in the present through the class discussion and help them come up with new ideas that benefit them in their real-life problem-solving (Akpan \& Beard, 2016). This strategy can help students build self-confidence and encourage them to broaden their knowledge and facilitate their learning. According to Poon (2013), using teaching strategies that includes both traditional and technology learning can improve students learning and provoke them to participate actively in the learning process. This approach helps students trust on their capacity and be self-efficacy in learning (Redding \& Walberg, 2012). Teaching strategies can also align with the idealism methodology that is 
based on Socratic dialogue stimulating students' critical thinking. The teacher's role is as a guide for students in the classroom to facilitate their curiosity in learning. The instructor stimulates students by asking leading questions to help them looking for more knowledge (Gutek, 2013; Saritaş, 2016). Thus, the instructor's role is to facilitate the learning procedure for learners to motivate them to have critical thinking, engagement, and independent learning.

\section{Teaching Strategies}

The learning procedure is triangular. It is a process that is shared between the teacher as facilitator, the student as a learner, and the school as the provider of regulations ensuring credibility. Joint productive activity, language development, contextualization, challenging activities, and instructional conversation ensure that students receive a successful educational experience that targets their educational needs. In this regard, William Bagley's essentialism theory suggests that students should learn traditional subjects to give them a solid understanding of their of their learning (Lynch, 2018). This approach helps students use traditional academic knowledge as a foundation for developing critical thinking. According to Gardner, every individual possesses different degrees of intelligence, such as verbal-linguistic intelligence, logical-mathematical intelligence, spatial-visual intelligence, bodily-kinesthetic intelligence, musical intelligence, intrapersonal intelligence, naturalist intelligence, and existential intelligence (Northern Illinois University). Thus, a teacher should treat each student as a holistic social unit and recognize multiple aspects of their personality (i.e., mental, psychological, social, and environmental aspects). Treating a student holistically would help teachers encourage students to recognize areas they need to strengthen through using formal and informal educational processes. Thus, teachers should use various strategies that meet all students' educational needs as students learn and absorb knowledge differently. What is effective in teaching for one lesson might not be effective in another lesson, and what is effective for one student might not be effective for another. Thus, teachers should vary their teaching practice to fulfill different students' learning styles. To this end, the following methods can be suggested: presenting brief lectures that explain the lesson concepts through posing questions; brainstorming activities to encourage students to think about the lesson and present their opinions about the lesson in group discussion; group report; using online resources; and using PowerPoint.

\section{Presenting a Brief Lecture}

A brief lecture on learning materials helps a teacher explain the purpose of the course. Brief lectures can explain the lessons' concepts and objectives with some examples that make students accommodate the outlines of the knowledge related to the lesson and facilitate understanding the lesson. Thus, a lecture should make students feel that they are participating in presenting the lesson and encourage them to stimulate their brains to provide ideas about the topic and link those ideas to their experience. According to Kelly (2019), a lecture should encourage students to break the ice between themselves and their teacher. Moreover, using teaching techniques in lecture such as posing questions can engage students in class discussion. This strategy encourages students to think critically and analyze the knowledge presented in class. According to Leammson (2002), lecture is effective when it leads to deep learning through integrating interactive strategies, such as using class activities along with lecturing to enhance students' thinking and engage them to participate in class discussion. Additionally, according to Wenzel (1999), a brief lecture is more effective than a long lecture (Cited in Konstantin, 2021 ). Furthermore, Corrigan (2013) emphasized that a lecture as a strategy of teaching should meet students' educational needs in order to engage them in their learning.

\section{Brainstorming}

Using brainstorming techniques in teaching invokes students' curiosity about the lesson. For example, for teaching on a topic like "Concept and Meaning of Social Development", the students can be divided into three groups: one group generates questions about the lesson, the second group generates ideas, and the third group makes a conclusion based on the presented ideas. This strategy can encourage students to generate ideas related to the lesson. According to Brown \& Palus (2002), brainstorming within a group is more effective than when it is done individually. In fact, the group generating questions thinks about the logical questions that have a relationship with the title of the lesson. The second group induces assumptions about the lesson, and the third group writes a brief group report as a conclusion. This strategy gives all students a chance to think and contribute to the learning process. There is no right or wrong answer about the concepts of social development, the purpose of this activity is to stimulate students to have critical thinking and learning engagement (Watson, 1991). Osborn defined brainstorming as a creative group activity which encourages individuals to present their ideas in an environment free from criticism and inspires individuals to link their ideas for obtaining favorable outcomes (Osborn, 1957). Osborn also stated that brainstorming could present unusual creative solutions to some problems (Osborn, 1957).

\section{Group Report}

The rationale of using group report activities is to encourage students to value each other's' opinions and write a concluding report for their work as a group. This activity has four objectives: each student feels their contribution has a value 
which leads them to build the self-confidence; each student learns not to criticize different ideas from their own group; each student looks for relevant information related to the class topic; and each student feels responsible for their findings and is encouraged to work with other students for the success of their team. A study showed that putting students in groups streamlines students' learning by discussing relevant topics and concepts (Lou et al., 1996).

This method encourages students to exchange their experiences and learn from each other. Moreover, this method induces students to provide new ideas and think about the class lesson from different perspectives (Hoch, 1961). According to research conducted by Roger Johnson, group work advances students' efforts and increases their educational achievement. It also increases their self-esteem and encourages them to adopt positive attitudes about the classroom environment as well as their classmates' contributions (Cited in Daugherty, 2014).

\section{Online Resources}

The rational of using online resources is to integrate online teaching methods with the traditional method to help students facilitate their understanding and encourage them to be self- learners. Hybrid learning makes students more interested in the class subjects and provides them an opportunity to satisfy their curiosity about learning. This would build self-confidence and motivate students to contribute into class activities (Savvidis, 2016; Mardiana, 2020).

There is evidence that using technology in the classroom has a positive effect on developing students' learning skills. Using the internet in the classroom and making it available to all students can help them develop their reading and writing skills. In fact, using technology in class not only develops students' educational skills, but also it helps an instructor facilitate the teaching process and track students' progress (Ramalingam, 2018). Achieving this goal would help students develop their technical skills. Thus, they could find and improve quality resources through various technologies. For instance, students could learn to use technologies to link the social work curriculum to online communications to improve their learning. Accessing online resource in the classroom helps students gain a deeper understanding of the class materials. According to Costen (2009), using technology in learning helps students have independent learning. Moreover, it helps students become more collaborative with each other and share their research findings and discuss their ideas in group. Using technology in class enhances the educational environment and helps students advance their critical thinking skills, be responsible for their learning, and learn how to use their knowledge.

\section{Using PowerPoint}

Using a brief presentation through PowerPoint at the end of the lesson can help the teacher to save class time and present the main ideas of the lesson in an organized way. This kind of presentation makes it easy for students to understand the lesson and review lesson key points (Susskind, 2004). Students can compare what they have learned during the class with what they find on the PowerPoint slides (Turner, 2010; Alkash \& Al-Dersi, 2013). A study showed using PowerPoint presentation in the classroom increases students' attentiveness and encourages them to be active in the learning process. Moreover, it allows both teacher and students to review the class materials in a short time (Lari, 2014).

\section{Conclusion}

The present paper presented a brief introduction of paradigm triangular in the teaching process. It also presented the teaching techniques and classroom activities that can improve and promote students learning. The paper addressed five strategies that effectively facilitate students' learning and meet their educational needs and stimulate their brains to expand their knowledge and learning. These strategies are: Giving short lecture as an introduction to the class topic, brainstorming that motivates students to involve in group discussion, group reports that help students summarize the class meeting, online resources that broaden students' knowledge, and using PowerPoint as a final review and conclusion of the class.

\section{References}

Akpan,J. P., \& Beard, L.A. (2016). Using constructivist teaching strategies to enhance academic outcomes of students with special needs. Universal Journal of Educational Research, 4(2), 392-398. https://files.eric.ed.gov/fulltext/EJ1089692.pdf

Alkash, K. A.,\& Al-Dersi , Z. E.( 2013). Advantages of using PowerPoint presentation in EFL classroom \& the status of its use in Sebha University. $\quad$ IJ-ELTS, $\quad 1(1), \quad 3-16$ https://citeseerx.ist.psu.edu/viewdoc/download?doi=10.1.1.673.2047\&rep=rep1\&type=pdf\#page=4

Corrigan, P. (2013) To lecture or not to lecture? Atlantic. https://www.theatlantic.com/education/archive/2013/12/to-lectureor-not-to-lecture/282585/

Costen, W. (2009). The value of staying connected with technology: An analysis exploring the impact of using a course management system on student learning. Journal of Hospitality, Leisure, Sport and Tourism Education. 8(2), 47-59 http://citeseerx.ist.psu.edu/viewdoc/download?doi=10.1.1.607.707\&rep=rep1\&type=pdf 
Daugherty, C. (2014). The benefits of collaborative learning in the elementary classroom. Sophia, the St. Catherine University repository. https://sophia.stkate.edu/maed/39

Gutek, G. L. (2013). Philosophical, theoretical, and ideological perspectives on education (2nd ed.). Boston: Allyn \& Bacon.

Hoch, L. (1961). Classroom grouping for effective leaning. New York University. http://www.ascd.org/ASCD/pdf/journals/ed_lead/el_196104_hock.pdf

Kelly, M. (2019). Lectures in schools: pros and cons. Though CO. https://www.thoughtco.com/lecture-pros-and-cons-8037

Konstantin, L. (2021). Problem- and case-based scenarios in teaching instrumental analytical chemistry: A two-level approach to trialling. Developing Academic Practice. https://doi.org/10.3828/dap.2021.7

Lari, F. (2014). The Impact of using PowerPoint presentations on students' learning and motivation in secondary schools. Procedia - Social and Behavioral Sciences, 98. 1672-1677. https://doi.org/10.1016/j.sbspro.2014.03.592

Leamnson, R. (2002). Learning (Your first job). https://www1.udel.edu/CIS/106/iaydin/07F/misc/firstJob.pdf

Lou, Y., Abrami, P., Spence, J., Poulsen, C., Chambers, B., \& d'Apollonia, S. (1996). Within-class grouping: A metaanalysi. American Educational Research Association. 66 (4), 423-458

https://www.jstor.org/stable/pdf/1170650.pdf?casa token=rjZWSYFz308AAAAA:eXRvV_KB0nLd5eJT24zt62MJky2kdAy 7JRBmG8jucYweitZdi

Lynch, M. (2018). Philosophies of education: 2 types of teacher-centered philosophies. The Edvocate. https://www.theedadvocate.org/philosophies-education-2-types-teacher-centered-philosophies/

Northern Illinois University. (n.d.). Howard Gardner's theory of multiple intelligences.

https://www.niu.edu/facdev/_pdf/guide/learning/howard_gardner_theory_multiple_intelligences.pdf

Mardiana, H. (2020). Lecturers' adaptability to technological change and its impact on the teaching process. Journal Pendidikan Indonesia (JPI), 9(2), 275-289 https://files.eric.ed.gov/fulltext/ED609075.pdf

Poon, J. (2013). Blended learning: An institutional approach for enhancing students' learning experiences. Journal of Online Learning and Teaching, 9(2), 271-288. http://dro.deakin.edu.au/eserv/DU:30057995/poon-blendedlearning-2013.pdf

Osbom, A.F. (1957). Applied imagination: Principles and procedures of creative problem-solving (third rev, ed,). New York, NY: Charles Scribner's Sons.

Ramalingam, D. (2018). Using data and technology to enhance classroom teaching. Brookings. https://www.brookings.edu/blog/education-plus-development/2018/02/09/using-data-and-technology-to-enhanceclassroom-teaching/

Redding, S., \& Walberg, H. J. (2012). Promoting learning in rural schools. Academic Development Institute. https://www.adi.org/downloads/Promoting_Learning_in_Rural_Schools.pdf

Saritaş, E. (2016). Relationship between philosophical preferences of classroom teachers and their teaching styles. Educational Research and Reviews, 11(16).1533-1541 https://files.eric.ed.gov/fulltext/EJ1111496.pdf

Savvidis, P.(2016). Top 6 benefits of using technology in the classroom. https://www.webanywhere.co.uk/blog/2016/02/top6-benefits-technology-classroom/

Susskind, J. (2004). PowerPoint's power in the classroom: enhancing students. http://ww2.gannon.edu/cetl/ppt/ppt\%20power\%20in\%20the\%20classroom.pdf

Turner, D. (2010). Power point presentations: 5 reasons to use power points. http://debbieturner.com/power-pointpresentations-5-reasons-to-use-power-points/

Training \& Technical Assistance Center. (2003). Science strategies considerations packet. William \& Mary; School of education. https://education.wm.edu/centers/ttac/documents/packets/sciencestrategies.pdf

Watson,S. (1991). How to brainstorm in the classroom. Thought CO. https://www.thoughtco.com/brainstorm-in-theclassroom-3111340 